\title{
STUDY OF THE MORPHOLOGO-ANATOMIC SIGNS OF SHOOTS OF THE SALIX CAPREA L. OF UKRAINIAN FLORA
}

\author{
N. Borodina, V. Kovalyov, O. Koshovyi, O. Gamulya
}

\begin{abstract}
Представники родини Salicaceае - иінні джерела лікарської рослинної сировини,яка здавна застосовується в народній медицині у багатьох краӥнах світу. В Свропейських краӥнах деякі види роду верба є офіційними рослинами. Кора молодих гілок різних видів роду верба, включаючи Salix purpurea L., Salix fragilis L., Salix daphnoides Vill., включена у видання європейської фармакопеї, а з 2014 року до Державної Фармакопеї України. Розширення сировинної бази лікарської рослинної сировини є актуальною проблемою, яку можливо вирішити за рахунок введення в фармацевтичну практику систематично близьких автохтонних та інтродукованих видів верб широко поширених в Украӥні.
\end{abstract}

Mета. Визначення макро- та мікроскопічних діагностичних ознак пагонів верби козячої (Salix caprea L.), що виростає в умовах України, для розробки в подальшому нормативної документації на лікарську рослинну сировину та застосування стандартизованої сировини при створенні лікарських засобів на основі пагонів верби.

Методи дослідження. Об'єктом дослідження були сухі пагони Salix caprea L. Рослинну сировину збирали в травні-серпні 2016-2018 роках в Харківській, Закарпатській та Київській області Украӥни.

Дослідження морфолого-анатомічної будови пагонів верби козячої проводили з застосуванням методів світлової та електронної мікроскопї. Ультраструктуру поверхні епідермальної тканини листків додатково вивчали, використовуючи методи скануючої мікроскопії.

Результати дослідження. Проведено поглиблене вивчення морфолого-анатомічної будови пагонів Salix caprea L. та встановлені основні діагностичні макро- та мікроскопічні ознаки перспективної лікарської сировини.

Висновки. Отримані результати значно розширюють відомості щодо анатомічної будови пагонів Salix сартеа L. флори Украӥни та будуть використані при стандартизації сировини видів родини Вербові

Ключові слова: Salix caprea L., пагони, макроскопічні ознаки, мікроскопічні ознаки, СЕМ, ультраструктура поверхні

Copyright (C) 2019, N. Borodina, V. Kovalyov, O. Koshovyi, O. Gamulya. This is an open access article under the CC BY license (http://creativecommons.org/licenses/by/4.0).

\section{Introduction}

Representatives of the Salicaceae family are valuable sources of medicinal plant material that has long been used in traditional medicine in many countries around the world. The sacred willow is highly respected among the Ukrainians, attributed to magical power. [1]. In European countries, some willow species are official plants. The bark of young branches of different willow species, including Salix purpurea L., Salix fragilis L., Salix daphnoides Vill., have been included in the publication of the European Pharmacopoeia [2, 3], and since 2014 the State Pharmacopoeia of Ukraine [4].

The genus Willow (Salix L.) according to various data includes 350-600 species [5, 6]. In the natural flora of Ukraine there are 24 species of the Salix genus [7], belonging to three subgenera and 16 sections [8,9]. The goat willow - Salix caprea L. (the willow family - Salicaceae, belongs to the Vetrix subgenus, Vetrix section) a small tree with a height of 2 to 8 (10) $\mathrm{m}$. Often has the form of a large tall shrub $[8,10]$. The trunk and branches are covered with a grayish-green bark. The bark smooth with age turns brown, cracks appear at the bottom of the trunk. The wood is smooth, red in the air. The branches are thick, spreading, young - grayish, pubescent, in older trees - yellow-brown and gray-green, in older plants gray or dark, brittle. The kidneys are glabrous, large, up to $5 \mathrm{~mm}$ long, up to $3 \mathrm{~mm}$ wide. Flower buds ovate, red, large, up to $15 \mathrm{~mm}$ long, 3-6 mm wide, not flattened. Earrings thick, large, 30-40 mm long. Male earrings wide, oval or oblong up to $6 \mathrm{~cm}$ long, Female - cylindrical, dense, multicoloured up to $10 \mathrm{~cm}$ long, on the legs. Fruit - a box, 7-8 cm, on a fluffy petiole. Each box contains up to 18 pieces of seeds. The seeds are provided with fluffy volatiles, so they are easily transported by wind over long distances, quickly lose their germination. Propagated solely by seeds, unlike other types of willow unable to propagate by cuttings. Goat willow blooms in April, before the leaves bloom [11]. Goat willow is a valuable honey plant. It is the earliest spring melliferous and pollen, and is the richest in other species of willow by its nectar. Distributed in Europe [9, 11], in the Caucasus, Western and Central Asia. [11, 12]. Due to the high growth rate, willow species are widely grown for bioenergy purposes as solid biofuels [12, 13]. Ukraine, it is growing throughout the territory, although it is more common in the north, in forests, on the edges, among shrubs, along the shores of rivers. [14, 15]. In addition, culture is widespread in Ukraine. [7, 9]. 
Expanding the raw material base of medicinal plant raw materials of plants of the Salicaceae family is an urgent problem that can be solved by introducing into the pharmaceutical practice systematically close autochthonous [7, 9] and introduced willow species widespread in Ukraine.

Despite the fact that some willow species have been official in Ukraine since 2014, many questions remain regarding the rational use and standardization of new medicinal plant raw materials of the Salicaceae family of Ukraine's flora [16, 17]. In this regard, it is relevant to study the morphological and anatomical structure of different species, varieties and hybrid forms of willows, which will allow to expand the range of medicinal plant raw materials both at the expense of autochthonous and at the expense of introduced willow species widespread in Ukraine.

Studies of the anatomical structure of willow species have not been carried out sufficiently. Published materials of morphological and anatomical study of the bark and shoots of white willow [18, 19], almond-leaved willow and purple willow $[15,20]$. There is data on the anatomical description of the bark of the drooping willow. According to the literature, willow bark preparations have a wide range of therapeutic properties: [21, 22], analgesic, antimicrobial [23, 24], sedative, anti-inflammatory, antipyretic [6, 23], diaphoretic, antimalarial, antiseptic, haemostatic and wound healing [22]. To understand the perspective of the use of medicinal plants in medical practice, it is customary to evaluate their chemical composition and pharmacological properties. Attention was paid to the study of biologically active substances of willow plant [21, 25]. Previously, they were found to contain different classes of natural compounds phenologic glycosides [26, 27], volatile compounds [25, 28], carbohydrates, amino acids, macro- and microelements, lipophilic compounds [2, 25]. Literary data indicate that phenolic compounds are predominant in the chemical composition [26, 37] (phenol-alcohols, hydroxybutyric and hydroxybenzoic acids, coumarins, flavonoids, tannins) [4, 29]. The authors of the article determined volatile [30, 31] and phenolic compounds of leaves of Salix caprea L. [29]. Also, with the GC/MS method were studied the volatile compounds and carboxylic acids of Salix cinerea L. [28] and Salix rosmarinifólia L. [32], Salix myrsinifolia Salisb. [33]. The elemental composition of some species of willow flora of Ukraine has been determined [23, 34].

In order to substantiate the possibility of using plants of the genus Salix L. in medicine, it is necessary to develop a draft regulatory document on raw materials. Important sections that determine its authenticity are external features and microscopy, so there is a need to further study the morphological and anatomical structure of willow species.

The purpose of the study was to determine the macro- and microscopic diagnostic features of shoots of goat willow (Salix caprea L.) growing in Ukraine, for the development of further regulatory documentation for medicinal plant raw materials.

\section{Planning (methodology) of research}

We opted for the Salix caprea L. flora of Ukraine as an object of our study because this species of the Salicaceae family has a sufficient plant base and, as previous studies have shown, deserves further introduction into the practice of modern medicine. [29, 30].

In Ukraine, there are large natural resources of valuable species of medicinal plants, including those of the Willow family. Ukraine ranks 7th in Europe in terms of total stock and stands after Russia, Sweden, France, Germany, Poland and Finland. However, the resource potential of many valuable species is not infinite [13, 14]. Therefore, the identification of raw reserves of medicinal plants, justifying their non-exhausting use is essential. One way to make more efficient use of willow raw materials is to use, unlike traditional willow raw materials, bark, crown components, shoots, twigs and other biomass that appear after main cutting and are burned to this day. In addition, harvesting willow shoots as medicinal plant material is potentially possible with energy willow plantations, which are growing in volume every year. $[13,35]$. Therefore, we consider it a promising to study the willow shoots.

At this stage of development of regulatory documentation for medicinal plant raw material SPhU requires in particular to analyze the powdered raw material $[4,16]$. This is due to the planning stage of the experiment, the application of the microscopic method analysis, which is the main method for determining the identity of the crushed, cut, powdered medicinal herbal raw materials. Additional diagnostic features of the internal structure of the studied objects help to identify methods of electron scanning microscopy. Morphological and anatomical diagnostic features are the basis for rapid analysis of medicinal plant raw materials and important indicators of its quality.

\section{Materials and methods}

The object of the study were dry shoots of Salix caprea L. Vegetable raw materials were collected in 2016-2018 in Kharkiv (samples of raw materials were harvested in the botanical garden of KhNU named after V. N. Karazin and in the botanical garden of NUPh, Kharkiv), Zakarpattia (samples of raw materials over the Tisza River, near the village of Steblyvka, Khust district, Zakarpattia region), and Kyiv (samples of raw material from the collection of willows of the National Botanical Garden named after M.M. Grishko of the NAS of Ukraine) region of Ukraine. Shoots of 1 year were collected during the period of complete development of the assimilation system (June-July), at least three different trees and formed a combined sample. Raw material samples were dried at room temperature for 10 days, and the dried plant material was stored in well-closed bags on shelves at room temperature.

Manufacture and research of micropreparations were performed according to the methods described in detail in the articles of the $\mathrm{SPhU}[4,16]$. For microscopic examinations, vegetable raw material fixed in a mixture of glycerol-ethanol-water (1:1:1) and air-dried raw material were used, which was boiled in 3-5\% aqueous alkaline solution for 2-3 minutes, preventing unnecessary softening. After boiling, the material was washed 2-3 times with distilled water and a preparation of leaves and shoots was prepared from the surface, cross-section and powdered raw material $[36,37]$ in a solution of chloral hydrate. Diagnostic microscopic features were recorded using a «Granum» microscope at magnification $\times 40$, 
$\mathrm{x} 100, \mathrm{x} 400$ times. The pictures were taken using a SonyDSC-W80 camera [38, 39].

The ultrastructure of the epidermal leaf tissue surface was further studied using scanning microscopy techniques $[36,40]$. Intact fragments of plant leaves were selected, then fixed on a brass table and sprayed with a thin layer of gold and platinum in a vacuum setting. The ultrastructure of the leaf surface was studied using JSM-6060 LA SEM. The microstructure of the leaf surface was described according to the terminology summarized in [41-44].

\section{Results of the research}

The results of the morphological and anatomical study of Salix caprea L. shoots are shown in Fig. 1-15.

Macroscopic features of goat willow shoots (Fig. 1-3). A mixture of shoots $15-30 \mathrm{~cm}$ long and leaves that shattered in drying and storage. Young shoots glabrous or scattered pubescent dark red-brown, later turning gray-green, bark gray. The bark of the old branches becomes grayish in colour, they become brittle. In the axils of the leaves flower buds are presence. The leaves cover the shoots densely. Leaves petiolate, alternate, large, entire, dense from broadly ovoid, almost rounded sometimes to oblong-lanceolate. The edge of the leaf blade is unevenly toothed.

The leaves have a dark green colour, glabrous above, glossy, and later dull, grayish-pubescent, with 6-9 pairs of very protruding lateral veins. When flowering, leaves are white-tomentose. Petioles 8-20 mm long, expanded, glabrous or scattered pubescent at the base. The size of the leaf plate up to $11-18 \mathrm{~cm}$ long and 5-8 $\mathrm{cm}$ wide.

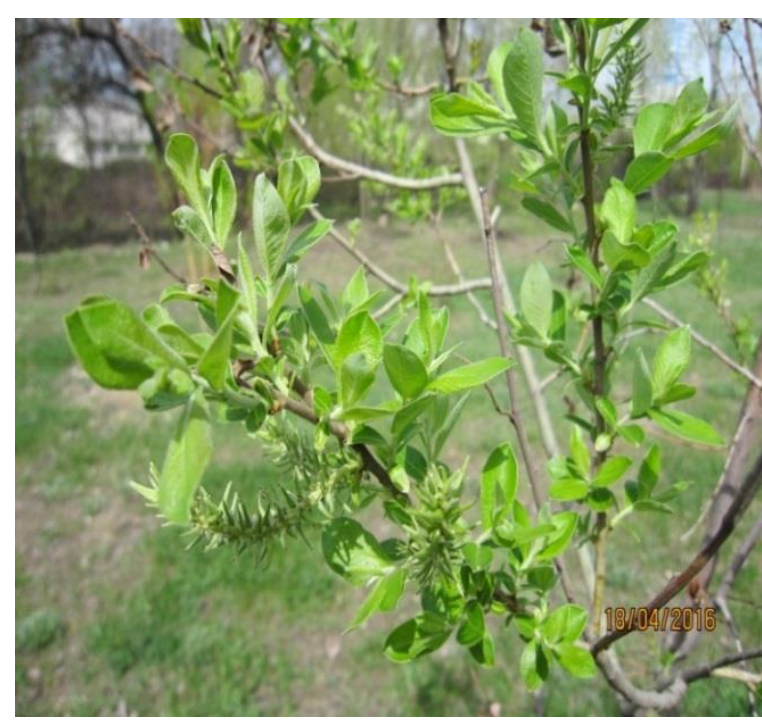

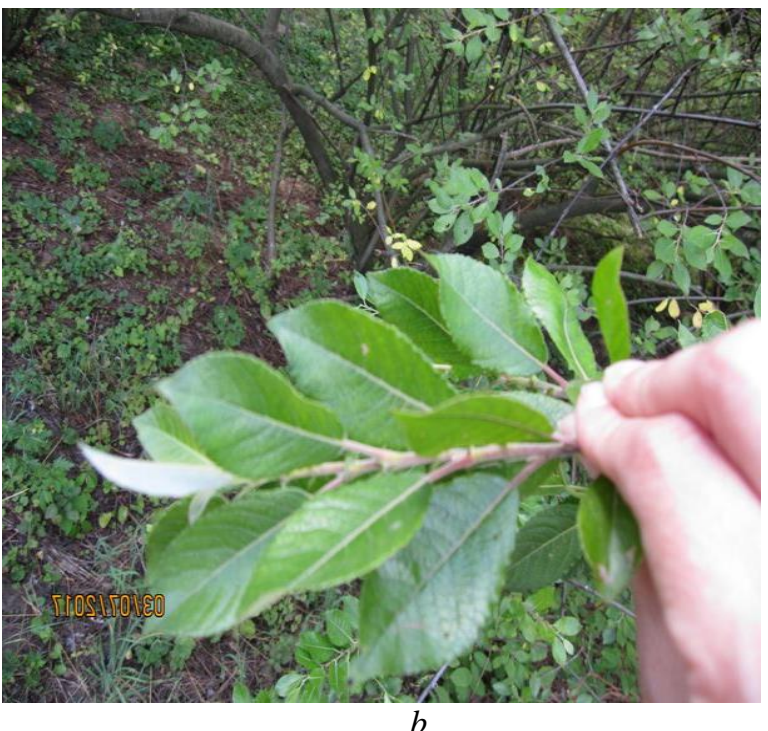

$b$

Fig. 1. Salix caprea L.(Botanical Garden of NUPh, Kharkiv, 2016): $a$ - the appearance of the plant.; $b$ - annual shoot
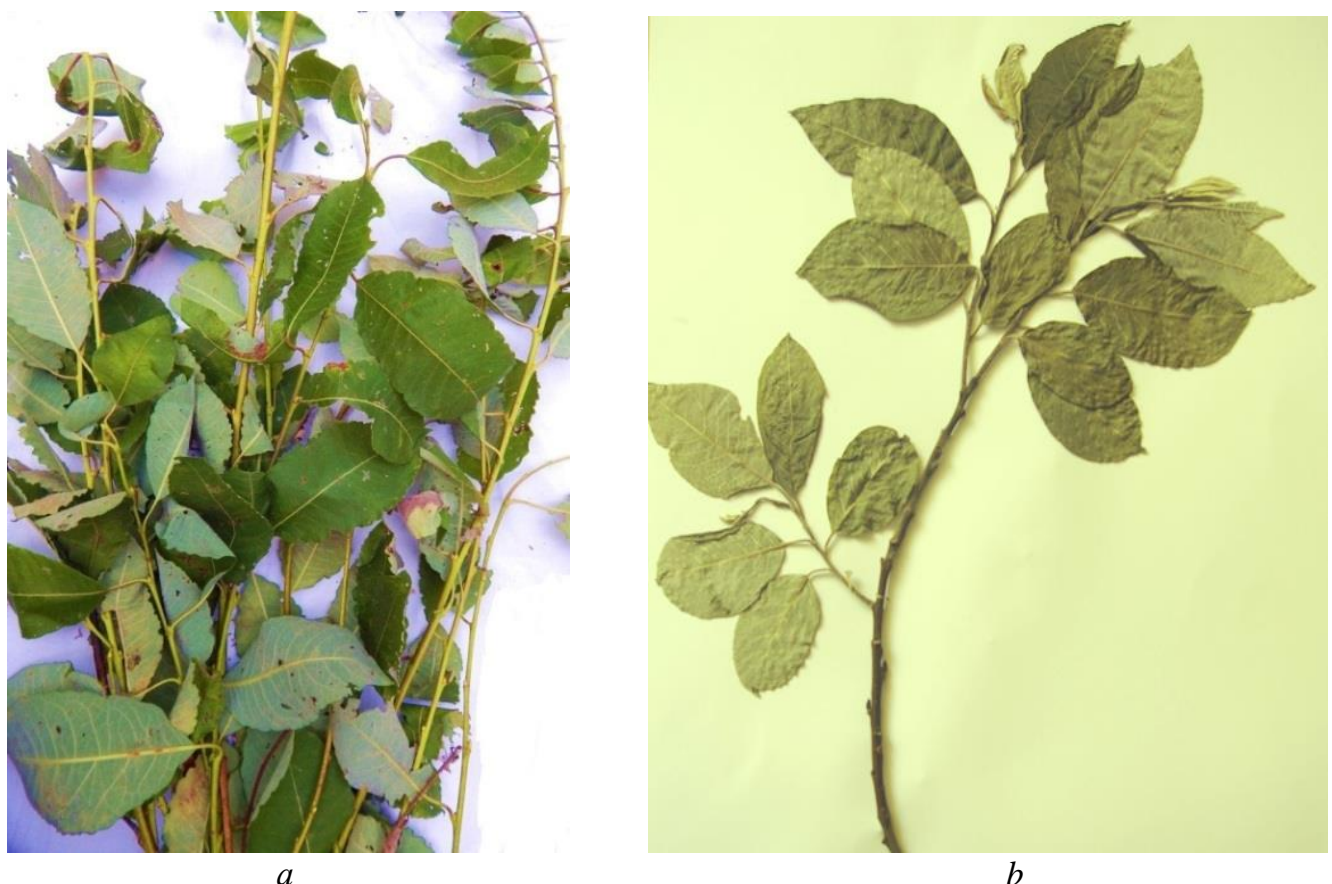

Fig. 2. Shoots of Salix caprea L.: $a$ - before drying; $b$-dried 


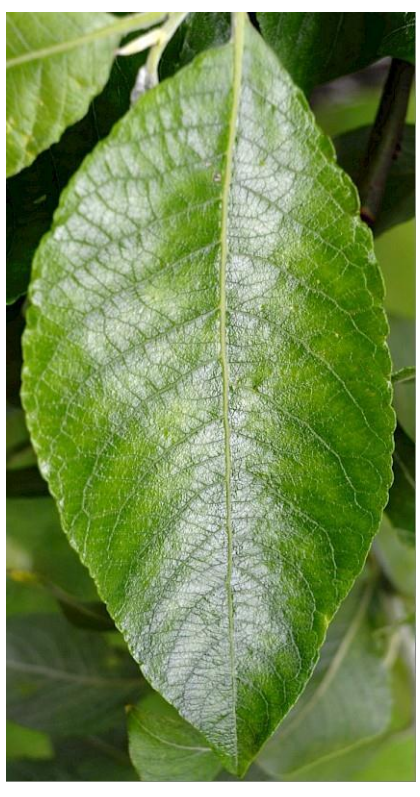

$a$

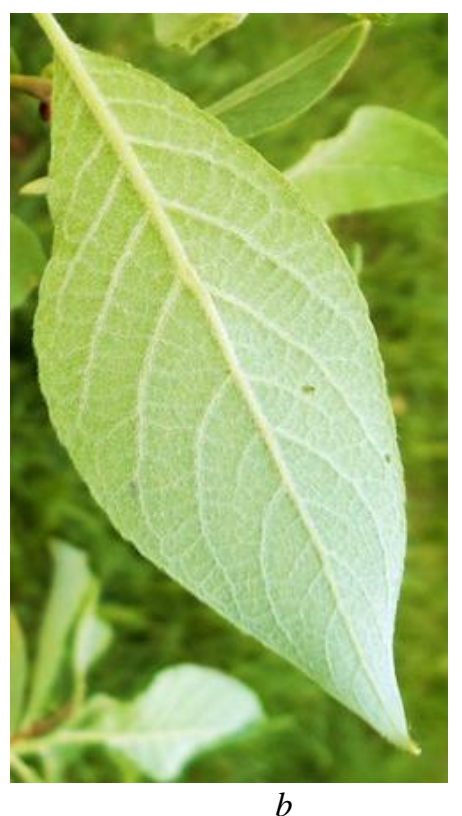

$b$

Fig 3. Leaves of Salix caprea L.: $a$ - the upper side; $b$ - the underside

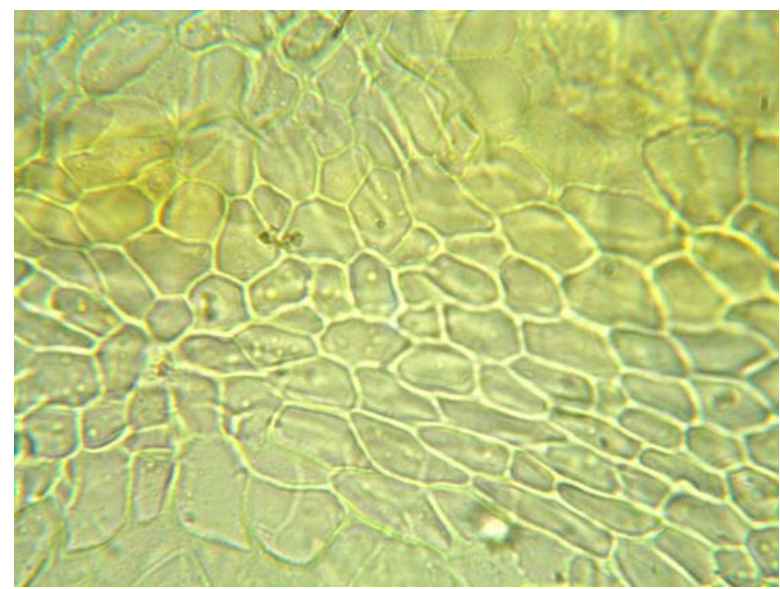

Fig. 4. The upper epidermis of the Salix caprea L. lamina (surface preparation)

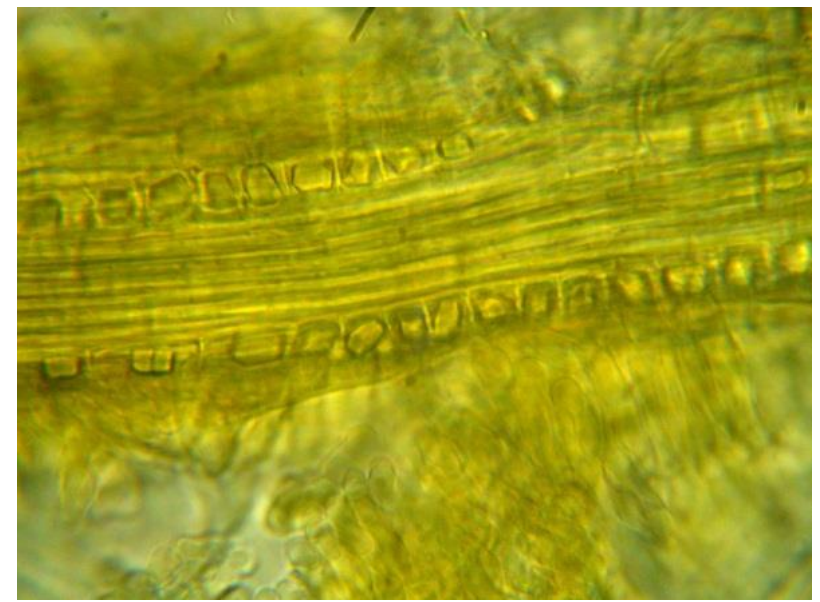

Fig. 5. Veins with crystals 


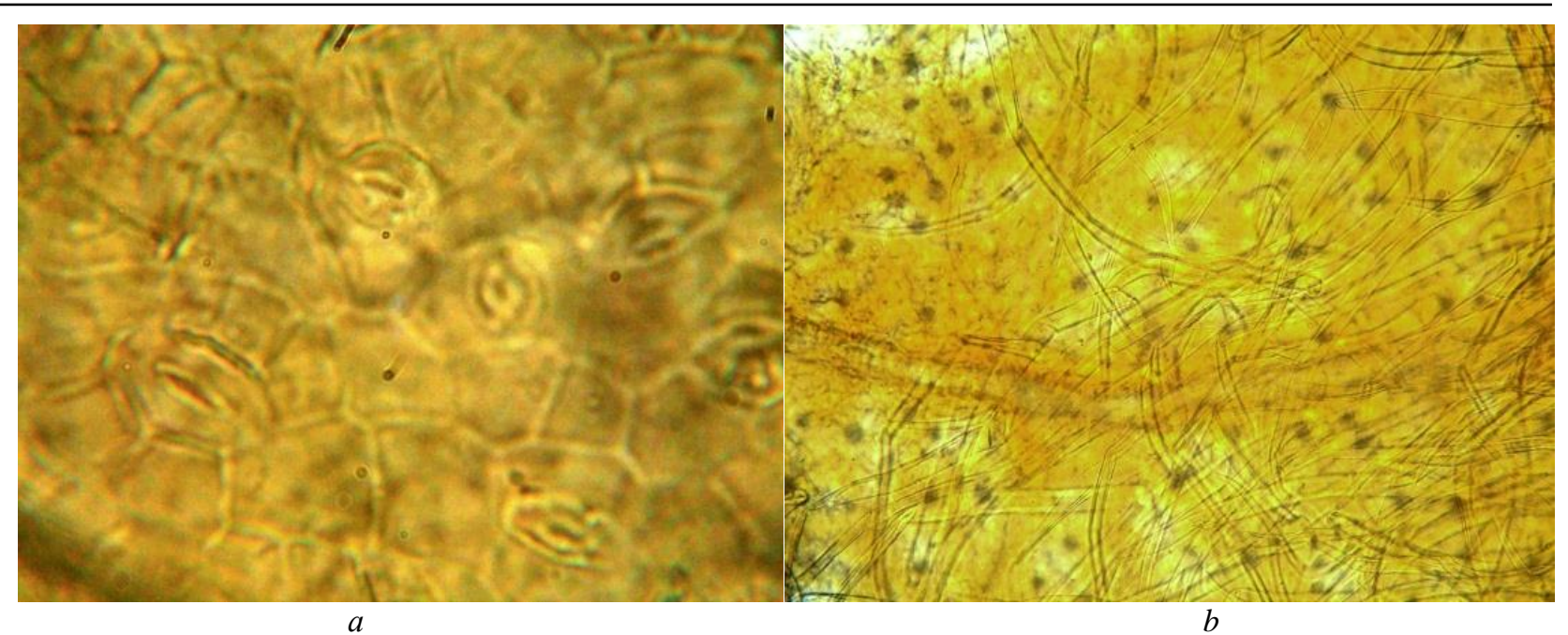

Fig. 6. The lower epidermis of the Salix caprea L. lamina (preparation from the surface): $a$-stomatas; $b$-calcium oxalate druses and fuzzes

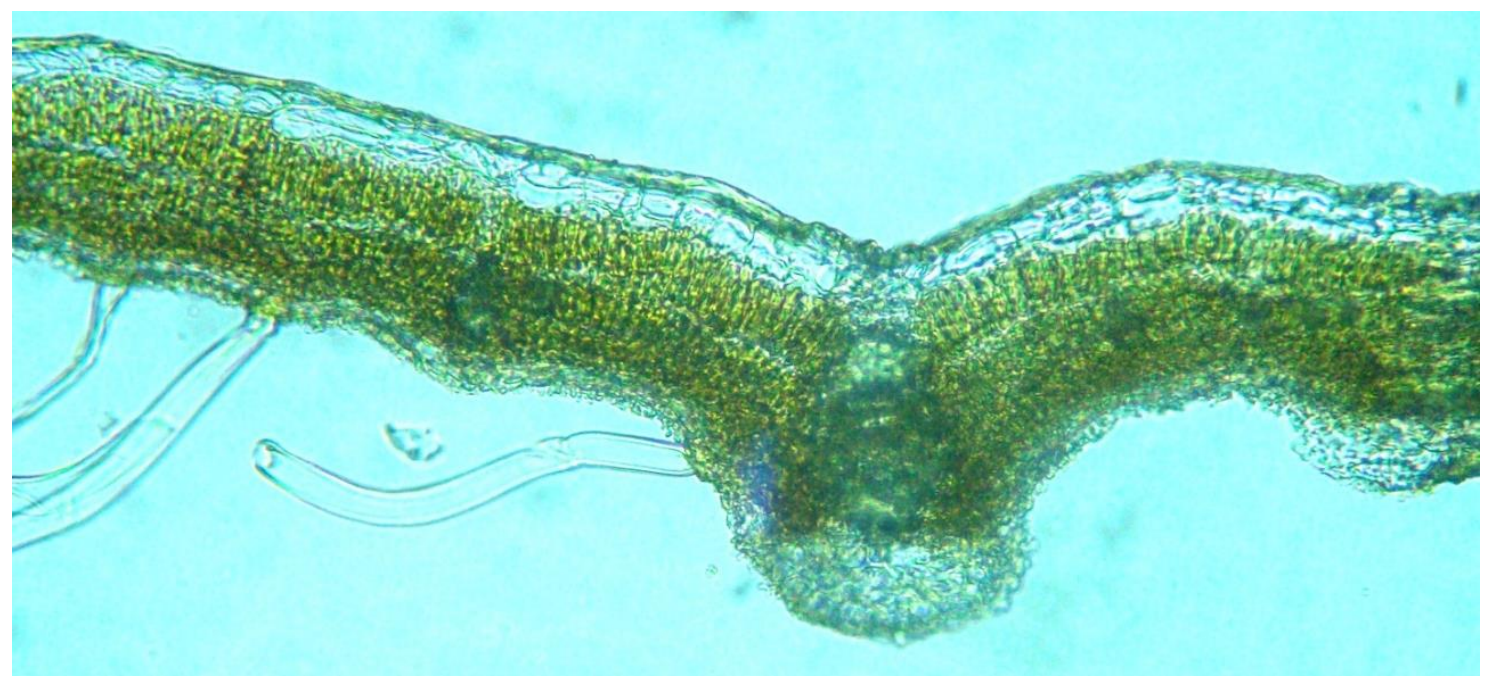

Fig. 7. Cross section of the Salix caprea L. lamina

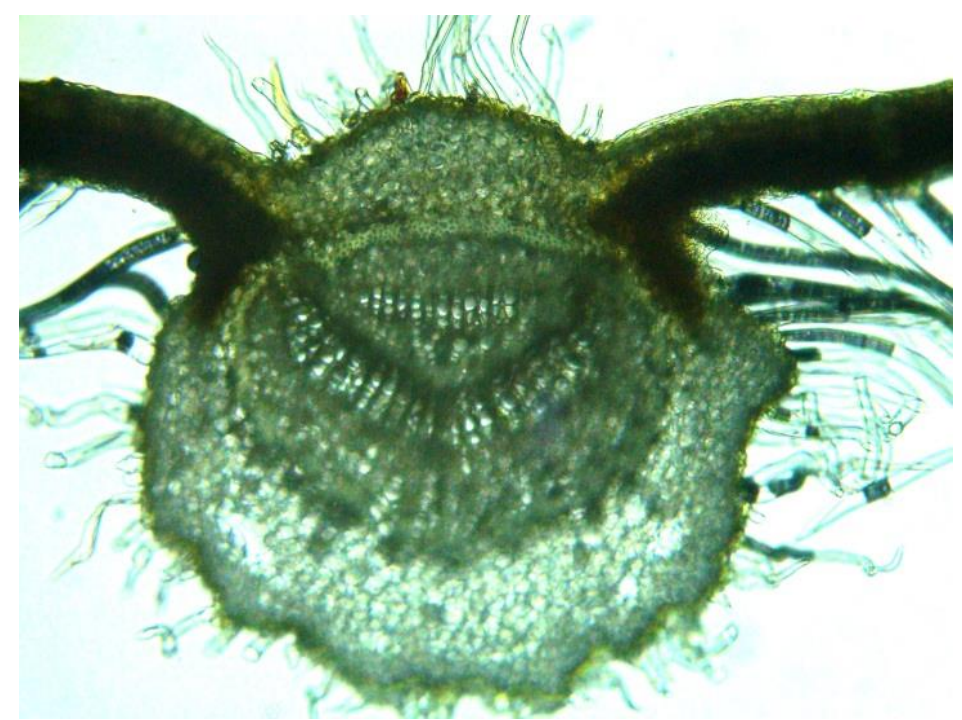

Fig. 8. Central vein of Salix caprea L. lamina (cross section) 


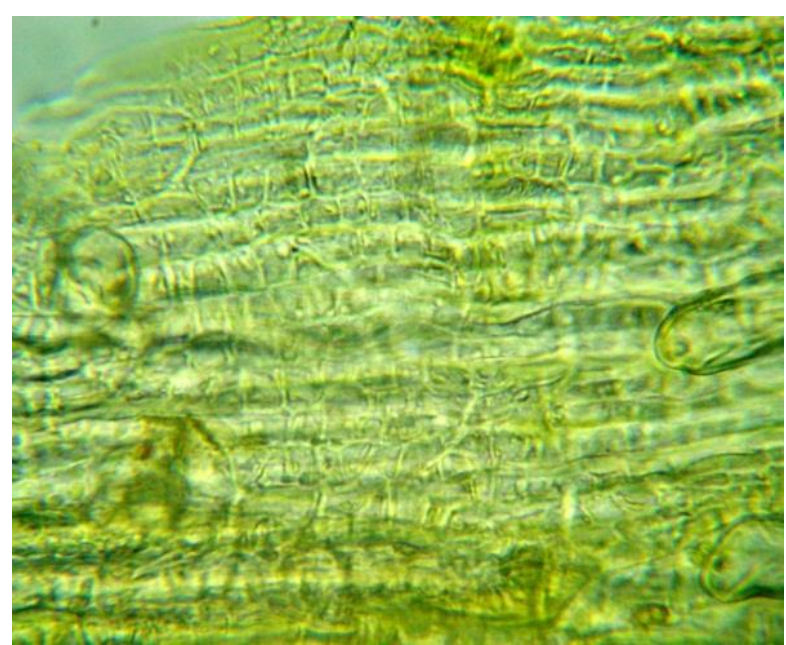

Fig. 9. Epidermis over vein of Salix caprea L. lamina (preparation from the surface)
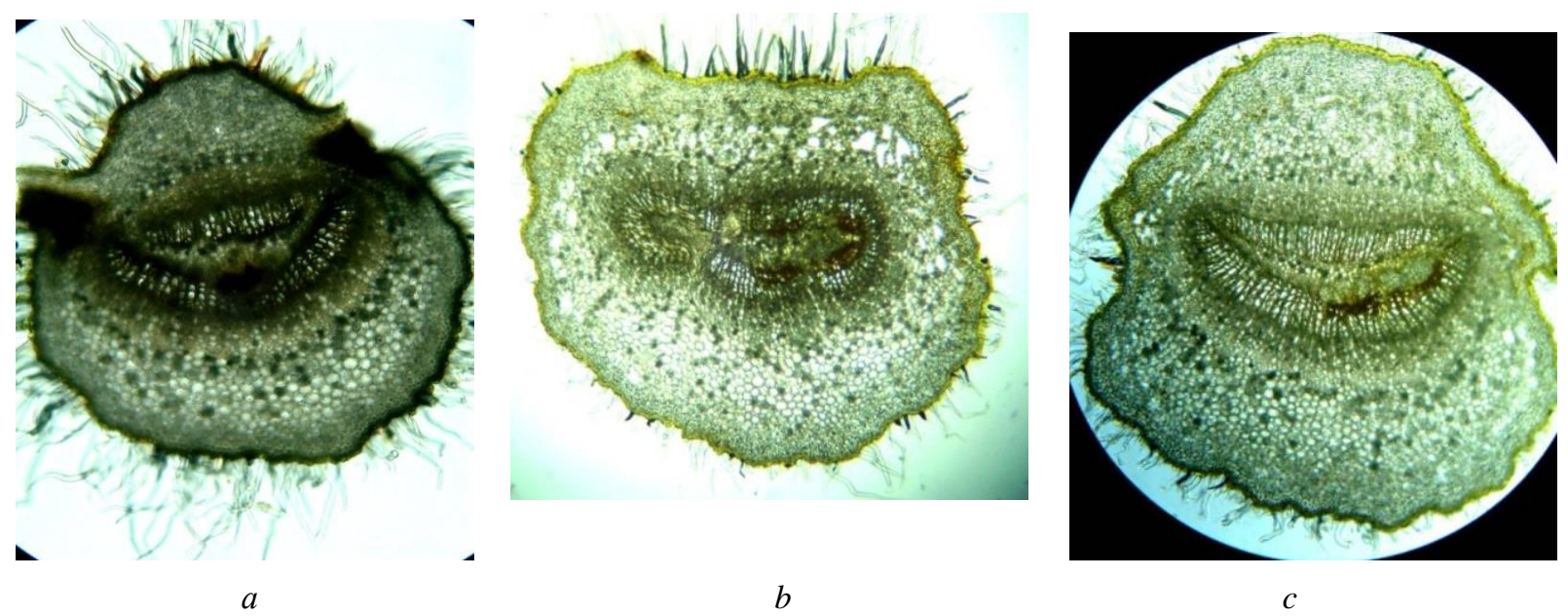

Fig. 10. The petiole of the willow leaf (cross section): $a$ - part of the leaf cushion; $b$ - the upper part; $c$ - the middle part

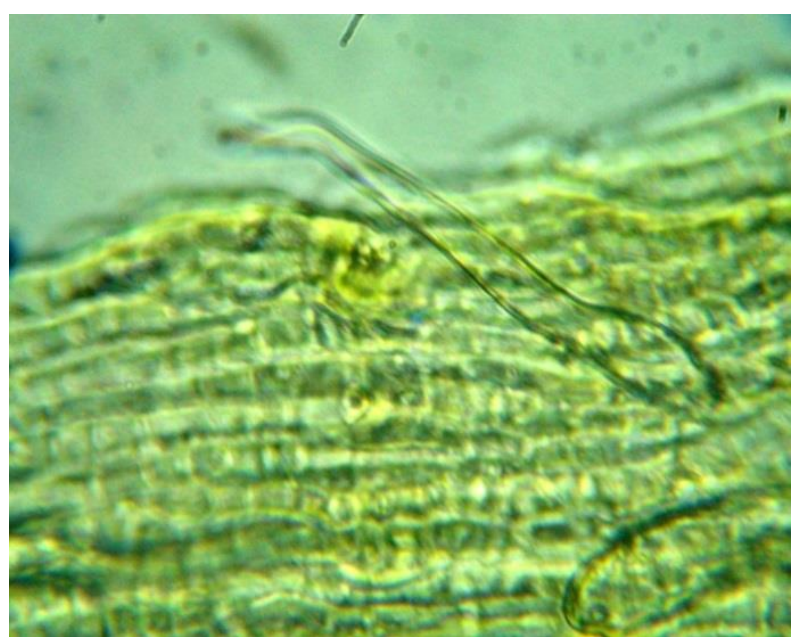

Fig. 11. Epidermis of the willow leaf petiole (surface preparation) 


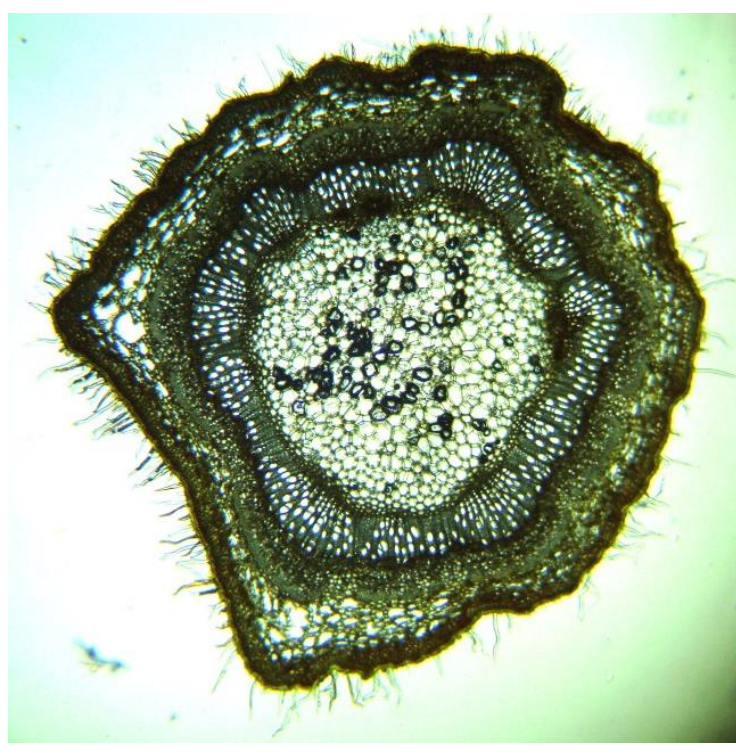

$a$

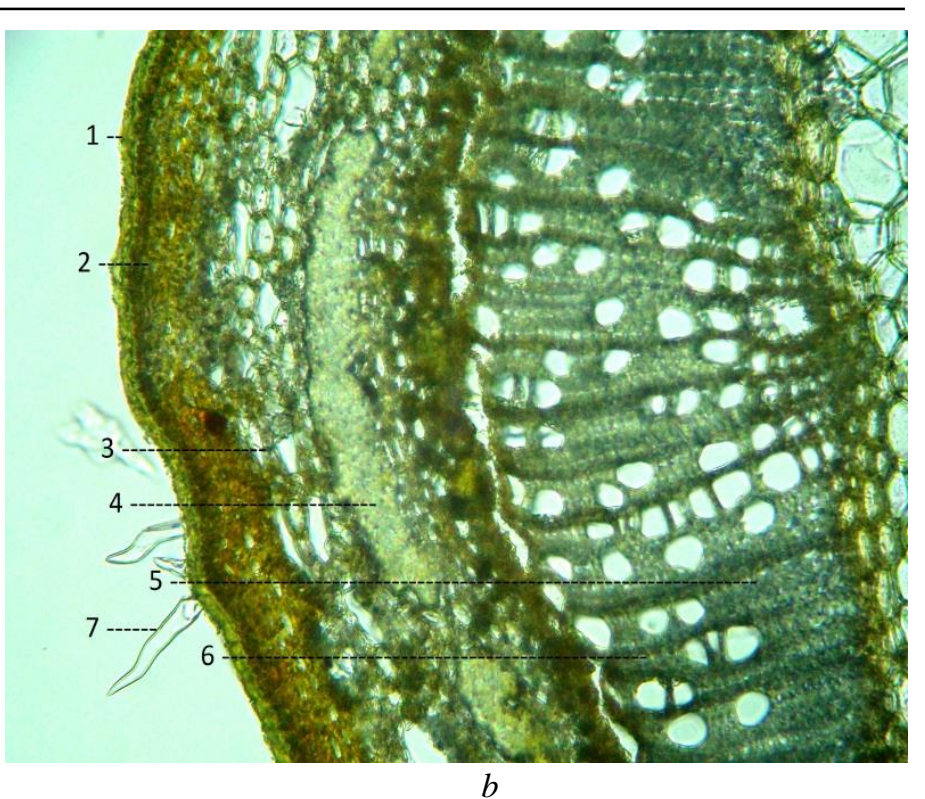

Fig. 12. Shoot Salix caprea L. of the 1 year (cross section): $a$ - rounded with two ribs; $b$ - anatomical structure of the shoot: 1 - epidermis; 2 - collenchyma; 3 - intercellular; 4 - sclerenchyma; 5 -xylem; 6 - core rays; 7 - fuzzes. primary parenchyma with large intercellular cells
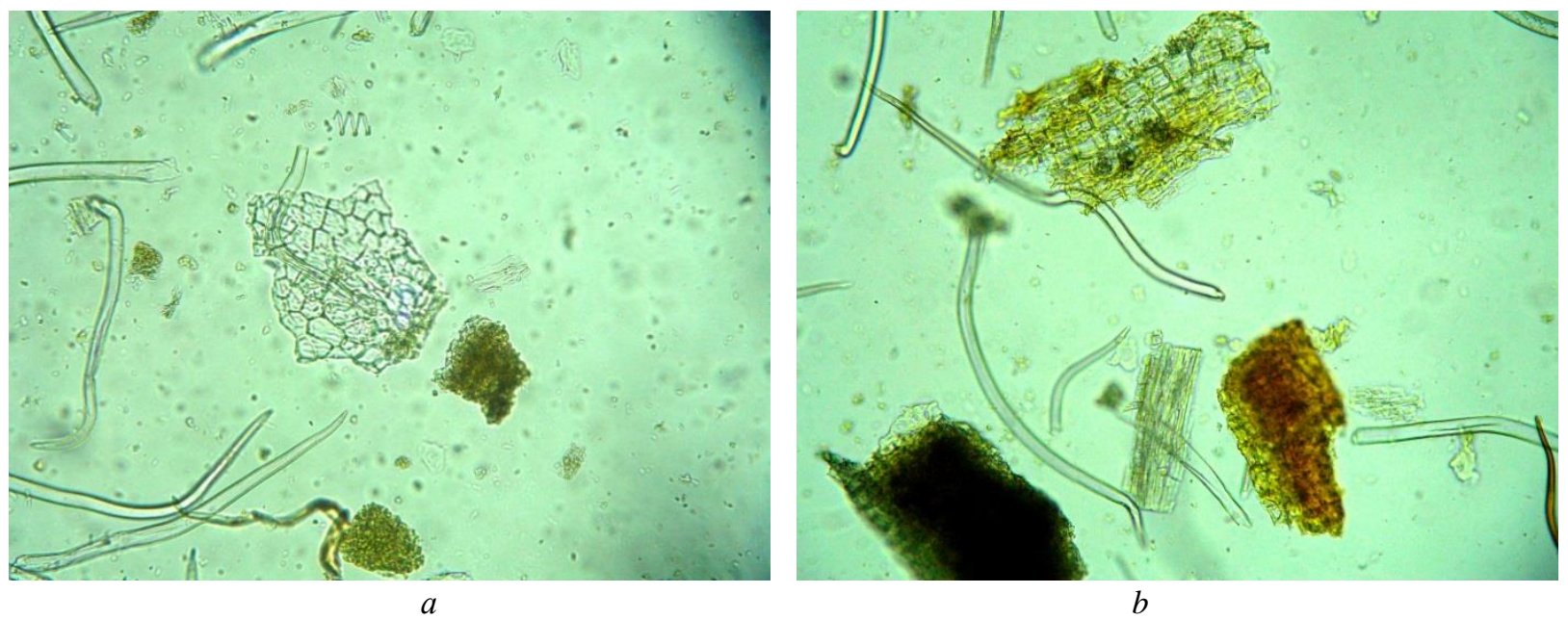

Fig. 13. Elements of powdered shoots of Salix caprea L.: $a$-separate fuzzes, sections of spiral vessels, fragments of leaf mesophyll; $b$ - bark fragments, phloem fibers, parenchyma with druses

Microscopic features of the structure of goat willow shoots. postatic.

Leaf plate has dorsiventral type of structure, hy-

The upper epidermis is represented by polygonal (parenchymal) cells with uniformly thickened membranes (Fig. 4) There are no upper stomatas on leaf plates. Simple unicellular fuzzes are present only on the veins, sometimes visible from the fallen hair (the place of hair attachment).

Ultrastructure of the surface. Adaxial surface of leaf plate aristate (Fig. 14). The epidermal cells have rectangular projections and elongated outlines. The anticlinal walls of the epidermal cells are not visible. Cell boundaries are not clear. The outer periclinal walls of the epidermis cells are convex. Cuticle well developed, striata. Single long, simple trichomes are present on the veins. On the adaxial surface of the leaf blade there is a well-developed epicuticular wax, which is represented by powerful films.

The inferior epidermis has a significant number of patches that differ in size. The type of breathing apparatus is anomocytic. The cells of the lower epidermis are much smaller in size than the cells of the upper epidermis (Fig. 5).

The lower epidermis is richly covered with hairs. Fuzzes simple, unicellular, thin-walled, with pointed tip and narrowed base. On the edge of the leaf blade (on the teeth, young leaves) there are multicellular glands, which later die. 


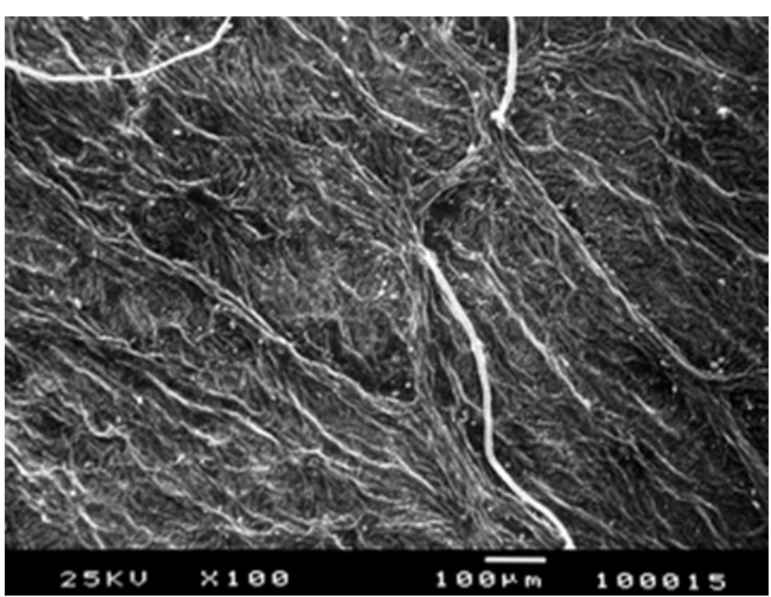

$a$

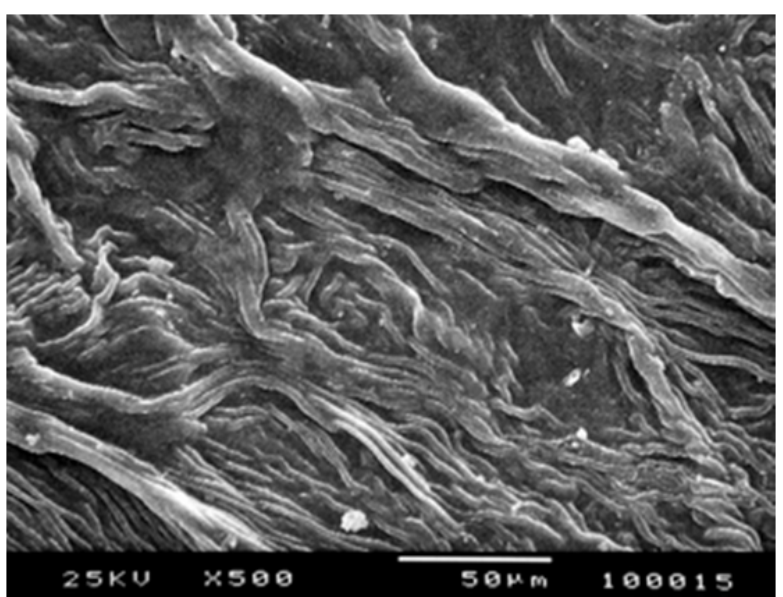

$b$

Fig. 14. Ultrastructure of the adaxial epidermis of the leaf blade of Salix caprea L $\therefore a$-fuzzes on the veins. $(\times 100) ; b$ - powerful epicuticular wax films $(\times 500)$
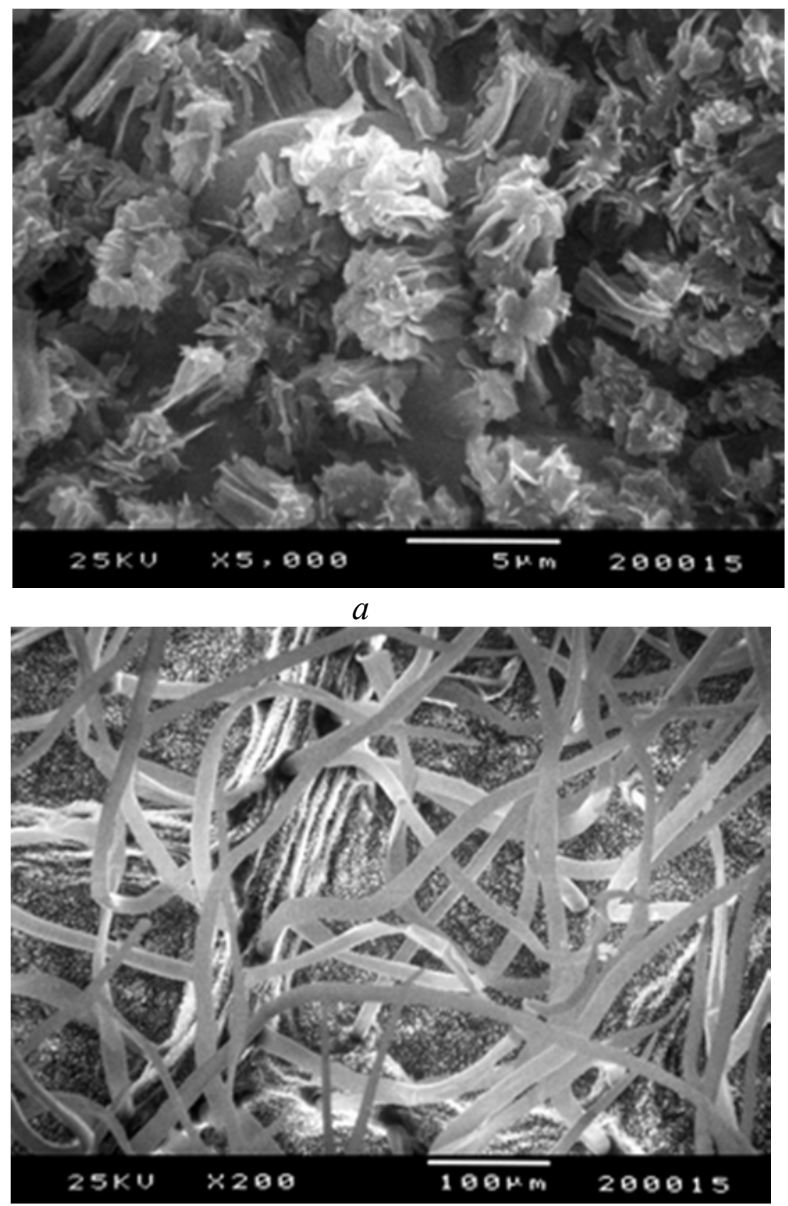

c

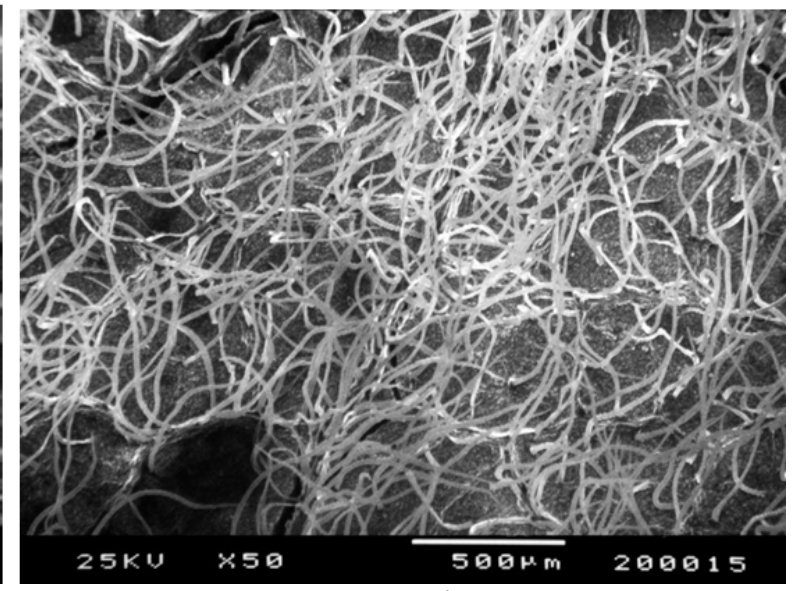

$b$

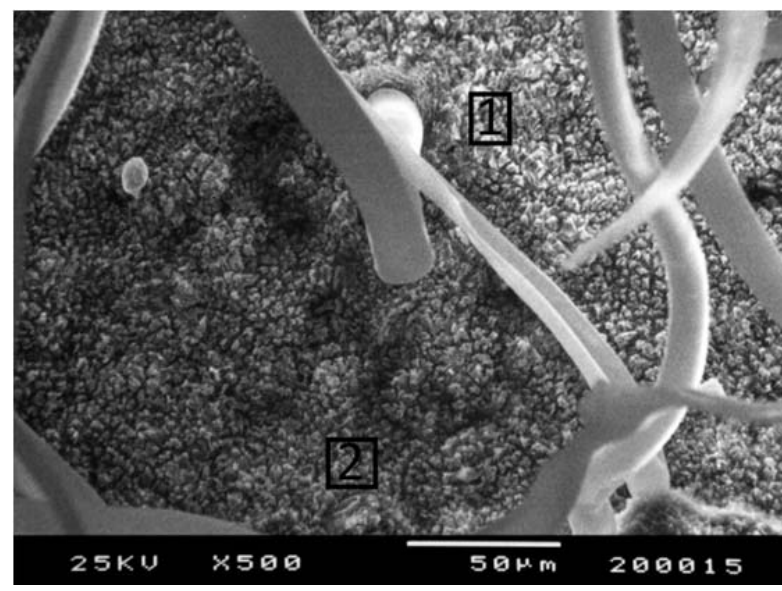

$d$

Fig. 15. Ultrastructure of the abaxial epidermis of the leaf blade Salix caprea L.: $a$-rodlets are aggregated in the longitudinal direction $(\times 5.000)$; $b$ - fuzzes $(\times 50)$; $c$ - fuzzes $(\times 200)$; $d$ - abaxial epidermis $(\times 500)$ : 1 - fuzzes; 2 - stomatas

Ultrastructure of the surface. In the studied species, the abaxial surface is clearly different from the adaxial one (Fig. 15). It is characterized by the presence of stomatas and a thick pubescence, which is formed by simple long trichomes. The cuticle is well developed. Epicuticular wax is represented by rodlets are aggregated in the longitudinal direction (massive sculptures of epicuticular wax of crystalloid form, often grouped in clusters [41]. In many cases, they are aggregated in the longitudinal direction).
The epidermis over the vein is small-celled (Fig. 9) Over the veins, the cells are elongated along the veins, mostly prosenchymal rectilinear, stomatas and trichomes are absent (Fig. 5).

On the transverse cuticle is dorsiventral (Fig. 7). There is a single layer of hypodermal cells under the upper epidermis. Mesophyll consists of cells that are very tightly located. In the mesophyll there are idioblasts with druses. Palisade parenchyma bilayer, cells of the upper 
layer more elongated. The spongy parenchyma, the cells are arranged tightly, the intercellular cells are almost absent, the cells are almost square in shape.

The central vein protrudes on both sides (Fig. 8). From the underside it forms a clearly visible rib. Vascular-fiber bundles have crystalline lining (Fig. 4). The central vein on the cross section is single-beam (Fig. 8). Subepidermal layer is represented by angular collenchyma. The main parenchyma of the central vein consists of large parenchyma cells. In the cells of the parenchyma there are druses, single crystals. The xylem of the central beam consists of spiral vessels. Core rays single-row. Phloem consists of small cells. On the outside of the phloem there are 1-2 layers of sclerenchyma. On the underside of the central vein, this layer is not integral. The phloem cells have druses.

The petiole is richly covered with fuzzes (Fig. 1011). Epidermal cells are small, parenchymal, often rectangular in shape (Fig. 12). At the base of the stem is triangularsickle-shaped. There are three conductive bundles: one central and two in shoots. Near the leaf pad, the petiole has an almost rounded shape (Fig. 10). A central conductive beam is formed from three beams. In the middle and upper parts of the upper side of the petiole formed a ledge. Under the epidermis (in cross section) is an angular colenchyme from 3 to 6 layers. The main parenchyma consists of rounded, large cells in which druses occur. In the layer of the parenchyma there are large intercellular cells. The anatomical structure of the petiole is similar to the structure of the central vein (Fig. 11).

Sprout. In the cross section at the top of the shoot has a rounded shape with two ribs (Fig. 13). The shoot is covered with simple long unicellular fuzzes with thin walls. Under the epidermis up to 6 layers of collenchyma. The parenchyma of the primary cortex is loose, with large intercellular cells (Fig. 13). Cells have chloroplasts, also available druses. Primary bast fibers are in groups of different sizes. As the branches grow, the sections of the bast merge into the ring of the bast. Xylem looks like a ring. The cells of the parenchyma of the xylem are thinwalled. Core rays single-row. Cells are thin-walled, polygonal.

Diagnostic features of the powder of goat willow shoots (Fig. 14): fragments of the epidermis with fuzzes, individual fuzzes, sections of spiral vessels, fragments of leaf mesophyll, fragments of conductive beams with crystalline cover, parenchyma with druses, fragments of the crust, phloem fibers (Fig. 14).

\section{Discussion of the results}

When conducting microscopic examinations, attention was paid to the diagnostic elements of shoots of epidermal cells, the type of lamina, the presence of the type of respiration, the characteristic of fuzzes. The results of the study confirmed that the shoots of goat willow have a characteristic structure of the stem for woody dicotyledon plant.

The leaves of many plants are characterized by a peculiar microrelief of the surface (outgrowth of cells, folds on their surface, deposition of wax crystals). Microrelief is taxon-specific and its features are used as diagnostics in botany and pharmacognosy in the identification of medicinal plant material. In modern scientific research, the methods of scanning electron microscopy (SEM) are used to determine the features of the microrelief structure of a plant surface. The study of the ultrastructure of the surface of the leaf Salix caprea L. revealed diagnostic micromorphological features: the type of surface relief, the type and orientation of the wax crystals, the type of trichomes, the location of respiration relative to the level of the main epidermal cells, which are of importance for the development of quality control techniques at the present level.

Study limitations. The microscopic method of analysis gives the most reliable results of identification of raw materials. However, in the course of our research, there were difficulties in the analysis of powdered willow raw material. When grinding raw materials, fuzzes are often broken off, crystals spilled, and attached to other parts of the powder, which does not always allow the authenticity of the raw material to be adequately established. In addition, close plant species are known to have very similar anatomical and diagnostic features, differing in frequency detection and sizes.

The prospects for further research are to continue pharmacognostic studies of Salix caprea L. shoots.

\section{Conclusions}

An in-depth study of the morphological and anatomical structure was performed and the main diagnostic features of Salix caprea L. shoots were established:

- shoot in cross section has a rounded shape with two ribs, covered with simple long unicellular fuzzes with thin walls, under the epidermis up to 6 layers of lamellar angiogenesis, parenchyma of the primary bark is loose, with large intercellular cells, fibers are present in size, xylem in the form of a ring, vessels are porous, core rays single-row.

- lamina of dorsiventral type of structure, hypostatic.

- the upper epidermis is polygonal, with uniformly thickened membranes, the upper side of the leaf plate stomatas absent, simple unicellular fuzzes present only on the veins.

- the lower epidermis has a considerable number of different respiration in size, the type of breathing apparatus is anomocytic, the cells of the lower epidermis are much smaller than the cells of the upper epidermis, abundantly covered with fuzzes, which are simple, unicellular, thin-walled, with a sharp acuminate.

- the crystalline inclusions of calcium oxalate are represented by druses and prismatic crystals located along the veins (crystalline lining).

- in the powder of the raw material there are fragments of the epidermis with fuzzes, individual fuzzes, sections of spiral vessels, fragments of mesophyll sheet, fragments of conductive bundles with crystalline lining, parenchyma with druses, xylem fibers, fragments of phloem.

The obtained data allow identification of Salix caprea L. raw materials.

For the first time, using the scanning electron microscope, the ultrastructure of the epidermal surface of the leaves of Salix caprea L. was investigated.

The obtained results significantly expand information on the anatomical structure of shoots of Salix 
caprea L. and will be used in the standardization of raw materials of species of the family Salicaceae.

\section{Conflict of interests}

There is no conflict of interest

\section{References}

1. Ishchuk, L. P. (2018). Verba v etnokulturnykh tradytsiiakh i zvychaiakh ukraintsiv. Etnobotanichni tradytsii v ahronomii, farmatsii ta sadovomu dyzaini. Uman: Sochinskyi M. M., 100-108.

2. European Pharmacopoeia. Vol. 1-2 (2010). Strassbourg: European Directorate for the Quality of Medicines \& Health Care (EDQM), 3536

3. Willow bark: British Pharmacopoeia. Vol. III (2009). London: Herbal Drugs and Herbal Drug Preparations, 3.

4. Derzhavna Farmakopeia Ukrainy. Vol. 3 (2014). Kharkiv: Derzhavne pidpryiemstvo «Ukrainskyi naukovyi farmakopeinyi tsentr yakosti likarskykh zasobiv», 732 .

5. Boeckler, G. A., Gershenzon, J., Unsicker, S. B. (2011). Phenolic glycosides of the Salicaceae and their role as antiherbivore defenses. Phytochemistry, 72 (13), 1497-1509. doi: http://doi.org/10.1016/j.phytochem.2011.01.038

6. Kishore, N. R., Mangilal, T., Anjaneyulu, N., Abhinayani, G., Sravya, N. (2014). Investigation of anti-inflammatory and in vitro antioxidant activities of hydroalcoholic extract of bark of Salix tetrasperma Roxb. International Journal of Pharmaceutics and Drug Analysis, 2 (5), 506-509.

7. Fuchylo, Ya. D., Sbytna, M. V. (2009). Vepby Ukpainy (biolohiia, ekolohiia, vykorystannia). Kyiv: Lohos, 200.

8. Horelov, O. M.; Kokhn, M. A. (Ed.) (2002). Rodyna Salicaceae Mirbel. Dendroflora Ukrainy. Dykorosli y kultyvovany dereva i kushchi. Pokrytonasynni. Chastyna I. Dovidnyk. Kyiv: Fitosotsiotsentr, 336-379.

9. Ishchuk, L. P. (2015). Rid Salix L. v Ukraini. Visti Biosfernoho zapovidnyka "Askaniia-Nova", 17, $35-43$.

10. Nedoseko, O. I. (2014). Borealnye vidy iv podrodov Salix i Vetrix: ontomorfogenez i zhiznennye formy. Nizhnii Novgorod: Izd-vo Nizhegorodskogo gosuniversiteta, 426.

11. Skvortsov, A. K. (1999). Willows of Russia and Adjacent Countries. Taxonomical and Geographical Revision. Joensuu: University of Joensuu, 307.

12. Mola-Yudego, B., González-Olabarria, J. R. (2010). Mapping the expansion and distribution of willow plantations for bioenergy in Sweden: Lessons to be learned about the spread of energy crops. Biomass and Bioenergy, 34 (4), 442-448. doi: http://doi.org/10.1016/j.biombioe.2009.12.008

13. Lakyda, P. I., Heletukha, H. H., Vasylyshyn, R. D. et. al.; Lakyda, P. I. (Ed.) (2011). Enerhetychnyi potentsial biomasy v Ukraini. Kyiv: Vydavnychyi tsentr NUBiP Ukrainy, 28.

14. Lakyda, P. I. (2001). Fitomasa lisiv Ukrainy. Ternopil: Zbruch, 256.

15. Khiteva, O. O. (2010). Sravnitelnoe morfologo-anatomicheskoe izuchenie kory trekh vidov ivy, proizrastaiuschikh na Severnom Kavkaze. Razrabotka, issledovanie i marketing novoi farmacevticheskoi produkcii, 65, 139-142.

16. Derzhavna Farmakopeia Ukrainy. Vol. 1 (2015). Kharkiv: Derzhavne pidpryiemstvo «Ukrainskyi naukovyi farmakopeinyi tsentr yakosti likarskykh zasobiv», 1128.

17. Kornilova, O. O., Makarova, O. Ye. (2015). Suchasni problemy standartyzatsii likarskoi roslynnoi syrovyny. Upravlinnia yakistiu v farmatsii. Kharkiv: Vyd-vo NFaU, 64-65.

18. Ternynko, I. I., Kyslychenko, V. S., Khvorost, O. P. (2012). Vyvchennia morfoloho-anatomichnykh oznak pahoniv ta lystia verby bilo. Farmatsevtychnyi chasopys, 2, 42-46.

19. Eremin, V. M., Shkuratova, N. V. (2007). Sravnitelnaia anatomiia kory ivovykh. Brest: BrGU im. A. S. Pushkina, 196.

20. Malychenko, E. V., Lotova, L. I. (1986). Anatomiia kory vidov roda Salix (Salicaceae) srednei polosy evropeiskoi chasti SSSR. Botanicheskii zhurnal, 71 (8), 106-113.

21. Ramos, P. A. B., Moreirinha, C., Santos, S. A. O., Almeida, A., Freire, C. S. R., Silva, A. M. S., Silvestre, A. J. D. (2019). Valorisation of bark lipophilic fractions from three Portuguese Salix species: A systematic study of the chemical composition and inhibitory activity on Escherichia coli. Industrial Crops and Products, 132, $245-252$. doi: http://doi.org/10.1016/j.indcrop.2019.02.028

22. Willow bark Salix spp. Analytical, quality control and therapeutic monograph (1999). American Herbal Pharmacopoeia and Therapeutic Compendium. Santa Cruz, 16.

23. Kurkin, V. A., Braslavskii, V. B., Zapesochnaia, G. G. et. al. (2000). Rasteniia semeistva ivovykh - perspektivnii istochnik novykh antimikrobnykh, protivovospalitelnykh i toniziruiuschikh lekarstvennykh sredstv. Poisk, razrabotka i vnedrenie novykh lekarstvennykh sredstv i organizacionnykh form farmacevticheskoi deiatelnosti. Tomsk, 42-43.

24. Islam, S. M., Zahan, R., Nahar, L., Alam, B. M., Naznin, M., Sarkar, G. C. et. al. (2011). Antibacterial, insecticidal and in vivo cytotoxicity activities of Salix tetrasperma. International Journal of Pharmaceutical Sciences and Research, 2 (8), 2103-2108.

25. Frolova, O. O., Kompanceva, E. V., Dementeva, T. M. (2016). Biologicheski aktivnye veschestva rastenii roda Iva (Salix L.). Pharmacy \& Pharmacology, 4 (2 (15)), 41-59.

26. Brereton, N. J. B., Berthod, N., Lafleur, B., Pedneault, K., Pitre, F. E., Labrecque, M. (2017). Extractable phenolic yield variation in five cultivars of mature short rotation coppice willow from four plantations in Quebec. Industrial Crops and Products, 97, 525-535. doi: http://doi.org/10.1016/j.indcrop.2016.12.049

27. Sulima, P., Krauze-Baranowska, M., Przyborowski, J. A. (2017). Variations in the chemical composition and content of salicylic glycosides in the bark of Salix purpurea from natural locations and their significance for breeding. Fitoterapia, 118, 118125. doi: http://doi.org/10.1016/j.fitote.2017.03.005

28. Borodina, N. V. (2016). Research of volatile compounds from Salix cinerea L. Oxford Review of Education and Science, $1(11), 468-473$.

29. Borodina, N. V., Kovalev, V. N. (2015). Sravnitelnii analiz fenolnykh soedinenii pobegov Salix caprea L., Salix purpurea L., Salix viminalis L. flory Ukrainy. Fenolnye soedineniia: fundamentalnye i prikladnye aspekty. Moscow, $27-33$.

30. Borodina, N. V. (2015). Izuchenie letuchikh komponentov Salix caprea L. Proceedings of 4-th European Conference on Biology and Medical Sciences. Vienna, 209-213.

31. Borodina, N. V. (2015). Khromato-mass-spektrometrycheskoe yzuchenye lystev Salix caprea L. Aktualni pytannia rozvytku medychnykh nauk u XXI st. Lviv: Lvivska medychna spilnota, 106-108. 
32. Borodina, N., Koshovyi, O., Kovalyov, V. (2016). The chromatography-mass spectrometry study of Salix rosmarinifolia L. Azerbaidzhanskii farmacevticheskii i Farmakoterapevticheskii zhurnal, XVI (2), 15-20.

33. Borodina, N. V., Kovalyov, V. N., Koshovyi, O. N., Stremoukhov, A. A. (2018). The study of Salix myrsinifolia Salisb. leaves by the GC/MS method. The 9th International Conference on Pharmaceutical Sciences and Pharmacy Practice, dedicated to the 100th years anniversary of independent Lithuania's pharmacy. Kaunas: LSMU, 105.

34. Borodina, N. V., Borova, E. B. (2015). Elemental composition of Salix caprea L. Topical issues of new drugs development. Kharkiv: Publishing Office NUPh, 62.

35. Smart, L. B., Volk, T. A., Lin, J., Kopp, R. F., Phillips, I. S., Cameron, K. D., Abrahamson, L. P. (2005). Genetic improvement of shrub willow (Salix spp.) crops for bioenergy and environmental applications in the United States. Unasylva, 56 (221), 51-55.

36. Barthlott, W., Mail, M., Bhushan, B., Koch, K. (2017). Plant Surfaces: Structures and Functions for Biomimetic Innovations. Nano-Micro Letters, 9 (2). doi: http://doi.org/10.1007/s40820-016-0125-1

37. Rudall, P. J. (2007). Anatomy of Flowering Plants. New York: Cambridge University Press, 146. doi: http://doi.org/10.1017/cbo9780511801709

38. Lotova, L. I. (2000). Morfologiia i anatomiia vysshikh rastenii. Moscow: Editorial URSS, 528.

39. Evert, R. F. (2006). Esau's Plant Anatomy. New York: Wiley-Interscience, 602. doi: http://doi.org/10.1002/0470047380

40. Dickison, W. C. (2000). Integrative plant anatomy. California: Elsevier, 533. doi: http://doi.org/10.1016/b978-0-12215170-5.x5000-6

41. Barthlott, W., Neithuis, C., Cytler, D., Ditsch, F., Meusel, I., Theisen, I. et. al. (2008). Classification and terminology of plant epicuticular waxes. Botanical Journal of the Linnean Society, 126 (3), 237-260. doi: http://doi.org/10.1006/bojl.1997.0137

42. Barthlott, W., Neinhuis, C., Cutler, D., Ditsch, F., Meusel, I., Theisen, I., Wilhelmi, H. (1998). Classification and terminology of plant epicuticular waxes. Botanical Journal of the Linnean Society, 126 (3), 237-260. doi: http://doi.org/10.1111/j.1095-8339.1998.tb02529.x

43. Borodina, N. V., Kovalov, V. M. (2018). Mineralnyi sklad deiakykh vydiv rodyny Salicaceae. Zbirnyk naukovykh prats spivrobitnykiv NMAPO im. P. L. Shupyka, 29, 180-187.

44. Kovalov, V. M., Marchyshyn, S. M., Khvorost, O. P. et. al.; Kovalov, V. M., Marchyshyn, S. M. (Eds.) (2014). Praktykum z identyfikatsii likarskoi roslynnoi syrovyny. Ternopil: TDMU, 264.

Received date 24.07.2019

Accepted date 15.08.2019

Published date 31.08.2019

Natalia Borodina, PhD, Associate Professor, Department of Pharmacognosy, National University of Pharmacy Pushkinska str., 53, Kharkiv, Ukraine, 61002

E-mail: natalijaborodina@gmail.com

Volodimir Kovalyov, Doctor of Pharmaceutical Sciences, Professor, Department of Pharmacognosy, National University of Pharmacy, Pushkinska str., 53, Kharkiv, Ukraine, 61002

E-mail: gnosy@nuph.edu.ua

Oleh Koshovyi, Doctor of Pharmaceutical Sciences, Professor, Head of Department, Department of Pharmacognosy, National University of Pharmacy, Pushkinska str., 53, Kharkiv, Ukraine, 61002

E-mail: oleh.koshovyi@gmail.com

Olga Gamulya, PhD, Senior Lecturer, Department of Fundamental and Language Training, National University of Pharmacy, Pushkinska str., 53, Kharkiv, Ukraine, 61002

E-mail: olga.gamulya@gmail.com 